\title{
Evolution of Single-Copy DNA and the ADH Gene in Seven Drosophilids
}

\author{
Laurence J. Zwiebel, Vivian H. Cohn, Donna R. Wright, and Gordon P. Moore
}

Division of Biological Sciences, Graduate Program in Cellular and Molecular Biology, The University of Michigan, Ann Arbor, Michigan 48109, USA

Summary. Single-copy DNA was isolated from Drosophila melanogaster and hybridized with total genomic DNA of $D$. melanogaster, $D$. mauritiana, $D$. simulans, $D$. pseudoobscura, $D$. willistoni, $D$. hydei and $D$. virilis. The duplexes were thermally eluted from hydroxyapatite and the data used to assess the relatedness of each species to $D$. melanogaster. The general pattern of relatedness was similar to that predicted by morphological methods but with some notable exceptions. The rate of nucleotide substitution was estimated to be greater than $0.66 \%$ of bases per million years. An unexpected, rapidly evolving component of $D$. melanogaster singlecopy DNA was identified. The relatedness of these species was also studied with respect to the gene coding for alcohol dehydrogenase (ADH). The ADH gene, previously cloned from $D$. melanogaster (Goldberg 1980), was hybridized with Southern blots of genomic digests of the seven species. The intensity and position of the hybridizing bands suggest the amount of divergence of the gene. Divergence was quantitated by reassociation of a fragment of the cloned $\mathrm{ADH}$ gene with total DNA of the seven drosophilids and thermal elution of the resultant duplexes from hydroxyapatite. The $\mathrm{ADH}$ gene was isolated from genomic clone libraries of $D$. melanogaster, $D$. simulans and $D$. mauritiana and further studied by comparison of position of restriction sites. Species relationships deduced from comparison of total single-copy DNA and the ADH gene were consistent, demonstrating that a single gene can reflect divergence of the entire genome.

Key words: D. melanogaster - Genomic evolution Thermal elution - Single-copy DNA - Alcohol dehydrogenase

Offprint requests to: G,P. Moore

\section{Introduction}

The idea that the course of evolution can be traced by analysis of biological macromolecules depends on the hypothesis that molecular divergence is linear with time (Wilson et al. 1977). As this concept has gained acceptance, phylogenetic analysis has moved to the molecular level. Interspecies molecular comparison have evolved from the study of biochemical properties of proteins (e.g. electrophoretic mobility, antigenicity, etc.) to their amino acid sequence and finally to the nucleotide sequence of DNA. Detailed interspecies comparison of individual genes has yielded important data regarding the processes of evolution (e.g. Perler et al. 1980; Efstratiadis et al. 1980). However, a disadvantage of fine-scale analysis is that only a minute fraction of the total genome can be studied using present methods. An alternative is analysis of DNA sequence relationships of a large fraction of the genome by hybridization/melting techniques. These procedures rely on the fact that mismatched DNA duplexes have a lowered melting point of about $1^{\circ} \mathrm{C}$ for each $1 \%$ of base mismatch (Hutton and Wetmur 1973). Single-copy DNA is prepared, labelled and hybridized with excess total DNA of the same (homologous) or different (heterologous) species (Britten and Kohne 1967; Kohne et al. 1971). The resultant duplexes are isolated and their thermal stability compared. The advantage of this method is that a huge number of DNA sequences are simultaneously compared. In the present study, we use interspecies comparisons at both the level of total single-copy DNA and a single cloned gene for an integrated view of evolution in drosophila.

Seven species of drosophila were chosen because of their position relative to Drosophila melanogaster in the evolutionary line of descent as deduced by morphological studies. As shown in Fig. 1 (adapted from Throck- 


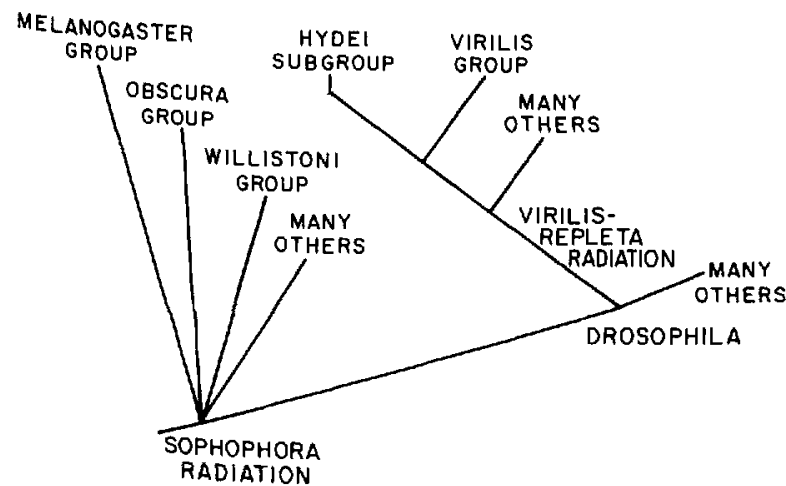

Fig. 1. Evolutionary line of descent of seven extant drosophilids (adapted from Throckmorton 1975)

morton 1975) the subgenus scaptodrosophila gave rise to the sophophora radiation, which includes the melanogaster group, as well as the drosophila radiation which itself gave rise to the virilis and repleta radiations. $D$. simulans and $D$. mouritiana were selected as members of the melanogaster group closely related to D. melanogaster. Indeed, $D$. simulans and $D$. melanogaster can be mated in the laboratory and probably form hybrids in nature as well (Sperlich 1962).D. pseudoobscura and $D$. willistoni were chosen to represent other groups in the sophophora radiation, while $D$. virilis and $D$. hydei represent the virilis-repleta radiation.

In addition to determination of the divergence of single-copy DNAs, evolution of the ADH gene has been studied. The ADH gene is particularly suitable for evolutionary comparison because it has been well characterized and cloned from $D$. melanogaster. Numerous ADH mutants exist and the gene has been mapped both genetically and cytologically. Electrophoretic variants of ADH protein have been identified, and their distribution in $D$. melanogaster populations studied. Moreover, the amino acid sequence of $D$. melanogaster $\mathrm{ADH}$ is known (Thatcher 1980) and the complete DNA sequence of the gene has been published (Benyajati et al. 1980, 1981). In the work reported here, genomic evolution in drosophila has been examined with respect to single-copy DNA relationships and sequence divergence of the ADH gene. We also describe isolation of clones containing the ADH gene from $D$. simulans and $D$. mauritiana and their preliminary characterization by restriction mapping.

\section{Materials and Methods}

Animal Procedures. The seven diosophilids were obtained from the Mid-Americas Drosophila Stock Center in Bowling Green, Ohio. All the species were maintained on standard $D$. melanogaster medium at $25^{\circ} \mathrm{C}$ except $D$. pseudoobscura which was maintained at $21^{\circ} \mathrm{C}$.

Isolation of DNA. DNA for the interspecies thermal melting experiments and for genomic blotting was isolated from adult flies frozen at $-70^{\circ} \mathrm{C}$. Five grams of flies werc ground first in a mortar, then in a Potter-Elvejen motor driven homogenizer in $0.05 \mathrm{M}$ Tris $\mathrm{pH} 7.6,0.025 \mathrm{M} \mathrm{KCl}, 0.05 \mathrm{M} \mathrm{Mg}$ acetate, $0.35 \mathrm{M}$ sucrose. The homogenate was centrifuged at $4000 \mathrm{rpm}$ in a Sorvall SS34 rotor for $15 \mathrm{~min}$ at $4^{\circ} \mathrm{C}$. The pellet was suspended in $0.15 \mathrm{M} \mathrm{NaCl}, 0.1 \mathrm{M}$ EDTA $\mathrm{pH} 8.0$, then adjusted to $2 \%$ SDS and heated to $60^{\circ} \mathrm{C}$ for $10 \mathrm{~min}$. The mixture was adjusted to $1 \mathrm{M}$ $\mathrm{NaHClO}_{4}$, titrated to $\mathrm{pH} 8.0$ and extracted once with redistilled phenol and three times with $24: 1$ chloroform/isoamyl alcohol. DNA was precipitated with ethanol, pelleted, and suspended in 0.1 X SSC. The mixture was incubated with $100 \mu \mathrm{g} / \mathrm{ml}$ preboiled RNAse A (Sigma) and 1500 units R Nase Tl (Sigma) for $2 \mathrm{~h}$ at $37^{\circ} \mathrm{C} .1000$ units of $\alpha$-amylase were added and incubation continued another hour. The DNA was again extracted with phenol and chloroform/isoamyl alcohol, precipitated and resuspended in $10 \mathrm{mM}$ Tris $\mathrm{pH} 8.0,1 \mathrm{mM}$ EDTA. Yields were about $1 \mathrm{mg}$ of DNA per $5 \mathrm{~g}$ flies.

Shearing and Sizing of Driver DNAs. DNAs uscd as driver in the thermal melting experiments were isolated as described above, and sheared by sonication in a Branson 185 cell disrupter. 200 $\mu \mathrm{g}$ of DNA were sonicated in $2 \mathrm{ml}$ of $10 \mathrm{mM}$ Tris $\mathrm{pH} 8.0,1 \mathrm{mM}$ EDTA for $40 \mathrm{~s}$ on setting 3.2. The single-strand size of the sheared DNAs was estimated from their electrophoretic mobility relative to standards on alkaline-agarose gels (Hall et al. 1980). The gels were $1 \%$ agarose, $30 \mathrm{mM} \mathrm{NaOH}, 2 \mathrm{mM}$ EDTA. Standards were $\emptyset \times 17 \mathrm{RF}$ DNA digested with Hae III and $\lambda$ DNA digested with Hind III. The gels were stained in $1 \mu \mathrm{g} / \mathrm{ml}$ ethidium bromide and photographed with a ycllow filter. As expected, the sheared DNAs had a broad length distribution. The mode of the length distribution was estimated to be approximately 1200 nucleotides for each driver DNA used.

Preparation of D. melanogaster Single-Copy Tracer. One hundred micrograms of total $D$. melanogaster (Oregon R) DNA were sonicated as described above then precipitated, resuspended in $1 \mathrm{ml}$ of $0.12 \mathrm{M}$ phosphate buffer pH $7.6(\mathrm{~PB}), 1 \mathrm{mM}$ EDTA, $0.05 \%$ SDS. The DNA was boiled 90 seconds in a sealed capillary tube then reassociated at $60^{\circ} \mathrm{C}$ to equivalent Cot $12 \mathrm{~mol}$ $1^{-1}$ s. A water-jacketed glass column was packed with $0.4 \mathrm{~g}$ of hydroxyapatite (BioRad DNA grade HAP lot 19693) and the DNA applied at $50^{\circ} \mathrm{C}, 0.12 \mathrm{M}$ PB. DNA which was not bound by HAP ( $81 \%$ of input) was dialyzed to $1 \mathrm{mM}$ EDTA, precipitated, resuspended in $0.1 \mathrm{mM}$ EDTA then adjusted to $0.41 \mathrm{M} \mathrm{PB}$ in $0.2 \mathrm{ml}$. This was boiled $90 \mathrm{~s}$, then reassociated at $60^{\circ} \mathrm{C}$ to equivalent Cot 1300 mol $1^{-1} \mathrm{~s}$. The reassociated DNA was dialyzed then labelled by the "gap-translation" method described by Galau et al. (1974) using ${ }^{3}$ H-GTP (NEN) and E. coli polymerase I (BRL) but no deoxyribonuclease. The specific activity of the tracer was $5 \times 10^{5} \mathrm{cpm} / \mu \mathrm{g}$. The tracer was precipitated, resuspended, adjusted to $0.12 \mathrm{M} \mathrm{PB}$ boiled, reassociated at $60^{\circ} \mathrm{C}$ to equivalent Cot $33 \mathrm{~mol} 1^{-1} \mathrm{~s}$ and fractionated on HAP as above. Removal of double-stranded material at this step eliminated artifactual foldback DNA generated during the gap-translation procedure and any remaining repetitive DNA. Material unbound by HAP was passed over a Sephadex G-100 column then bound to $\mathrm{HAP}$ in $0.012 \mathrm{M} \mathrm{PB}$ in order to remove unincorporated nucleotides and short fragments of DNA.

The single-strand length of the single-copy tracer was determined by centrifugation through an isokinetic alkaline sucrose gradient (Noll 1967). $V_{\text {mix }}=9.84 \mathrm{ml}, C_{\text {res }}=43 \%$ sucrose $(\mathrm{W} / \mathrm{V}), \mathrm{C}_{\mathrm{flask}}=16 \%$ sucrose $(\mathrm{W} / \mathrm{V})$ in $0.1 \mathrm{M} \mathrm{NaOH}$. Gradients were centrifuged at $33,000 \mathrm{rpm}$ for $30 \mathrm{~h}$ at $20^{\circ} \mathrm{C}$ in a Beckman SW41 rotor. The modal length of the tracer was determined in relation to internal standards previously sized in the electron microscope (Studier 1965). Sucrose gradients were fractionated and the absorbance at $260 \mathrm{~nm}$ measured. Each fraction was neutralized and counted in Aquasol 2 (NEN) in a liquid scintillation counter. Comparison of the migration of the ${ }^{3} \mathrm{H}$-labelled 
tracer to that of the optical standards indicated a modal length of 510 nucleotides.

Hybridization and Thermal Melting of Single-Copy DNA. Twenty-five micrograms of each sheared driver DNA were precipitated and resuspended in a final volume of $30 \mu 1$ of $0.41 \mathrm{M}$ PB, $1 \mathrm{mM}$ EDTA, $0.05 \%$ SDS. The drivers were sealed in capillary tubes with $10^{4} \mathrm{cpm}$ of $\mathrm{D}$. melanogaster single-copy tracer, boiled $60 \mathrm{~s}$ then reassociated to equivalent $\operatorname{Cot} \geqslant 2500 \mathrm{~mol} 1^{-1} \mathrm{~s}$ at $55^{\circ} \mathrm{C}$. The ratio of driver DNA to tracer DNA was 1000 . Samples were diluted to $1 \mathrm{ml}$ of $0.12 \mathrm{M} \mathrm{PB}$, then applied to $0.4 \mathrm{~g}$ HAP columns (three columns were run in serjes). Unbound material was washed away, then bound duplexes were eluted with $0.12 \mathrm{M}$ PB by increasing temperature in $4^{\circ} \mathrm{C}$ increments as described by Moore et al. (1978). Eluate was collected directly into scintillation vials and counted.

Genomic Southern Blotting. The gene coding for D. melanogaster (Canton S) ADH was isolated, subcloned into the plasmid pBR322, named pSAC and graciously provided by Dr. David Goldberg. As shown in Fig. 5, the subclone consists of the smallest genomic Eco RI fragment which contains the entire structural gene as well as about $1 \mathrm{~Kb}$ of flanking DNA in both directions. pSAC DNA was prepared by the method of Clewell and Helinski (1970) and ${ }^{32}$ P-labelled by nick-translation (Rigby et al. 1977) to specific activity $1-2 \times 10^{8} \mathrm{cpm} / \mu \mathrm{g}$ using all four $\alpha-32$ P-dNTP (NEN). DNA of the seven drosophilids, prepared as above, was digested twice with a 3 -fold excess of Eco $\mathrm{RI}$ and $2 \mu \mathrm{g}$ were electrophoresed in $0.7 \%$ agarose gels for $15 \mathrm{~h}$ at $70 \mathrm{~mA}$. DNA was transferred to nitrocellulose filters (BA 85 Schleicher and Schuell) using the Southern procedure (Southern 1975) except that denaturation was in $0.1 \mathrm{M} \mathrm{NaCl}, 0.5 \mathrm{NaOH}$ and neutralization was in $0.1 \mathrm{M} \mathrm{NaCl}, 0.5 \mathrm{M}$ Tris. Hybridization was performed in $50 \%$ formamide (Fisher), $5 \times \mathrm{XSC}, 0.1 \%$ SDS, $10 \%$ dextran sulfate at $34^{\circ} \mathrm{C}$. The filters were washed in $2 \mathrm{X}$ SSC, $0.1 \%$ SDS, $0.1 \% \mathrm{Na}$ pyrophosphate at $50^{\circ} \mathrm{C}$. Autoradiograms were exposed at $-70^{\circ} \mathrm{C}$ using Kodak XAR-S X-ray film and Kodak C-2 film cassettes with Dupont Lightening Plus intensifiying screens.

Labelling and Strand-Separation of a Fragment of pSAC. A 610 nucleotide fragment of pSAC was prepared by digestion with Bam HI and Hind III as shown in Fig. 5. Digestion products were end-labelled with $32 \mathrm{P}$ using modification of the procedure of Drouin and Symons (1979). Ten micrograms of pSAC were digested, precipitated and resuspended in a final reaction volume of $35 \mu \mathrm{l}$. Labelling was at $14^{\circ} \mathrm{C}$ for $1 \mathrm{~h}$ in $50 \mathrm{mM} \mathrm{NaCl}, 50 \mathrm{mM}$ Tris $\mathrm{pH} 7.4 .8 \mathrm{mM} \mathrm{MgCl}$ in the presence of 50 microcuries (1.85 $\times 10^{6}$ becquerels) of each $\alpha^{-3}$ P-dNTP (NEN; $3000 \mathrm{mCi}$ ) $\mathrm{mMol}$ ) and 2.5 units of the large fragment of $E$. coli DNA polymerase I (NEN) (Klenow and Hansen 1974). Labelled DNA was precipitated, then suspended in $25 \mu \mathrm{l}$ of $30 \%$ (vol/vol) dimethylsulfoxide, $1 \mathrm{mM}$ EDTA, $0.05 \%$ (wt/vol) xylene cyanol, $0.05 \%$ (wt $/ \mathrm{vol}$ ) bromphenol blue. Isolation of the 610 nucieotide fragment and separation of the DNA strands was performed as described by Maxam and Gilbert (1977) except that electrophoresis was in $4 \%$ (wt/vol) acrylamide crosslinked with $0.08 \%$ (wt/vol) methylene bis-acrylamide at 350 volts for $20 \mathrm{~h}$. The gel was stained with ethidium bromide in the presence of $5 \mathrm{mM}$ ammonium acetate and the separated strands of the 610 nucleotide fragment werc sliced out. DNA was eluted from the gel slices by diffusion into $10 \mathrm{mM}$ Tris, $1 \mathrm{mM}$ EDTA at $37^{\circ} \mathrm{C}$ overnight. The specific activity of the labelled, strand-separated tracer was estimated to be $3 \times 10^{6} \mathrm{cpm} / \mu \mathrm{g}$. For the hybridizations discussed below, the slower migrating band was used. This was the nonsense strand labelled at the Bam site. The extent of opposite strand contamination was measured as $7 \%$ by selfhybridization and binding to hydroxyapatite. The small amount of tracer-tracer duplex was normalized from the thermal elution curves of Fig. 4.

Hybridization and Thermal Elution of a Fragment of $p S A C$. Genomic DNA of seven drosophilids was prepared and sheared to a length of about 1000 nucleotides as described above. Aliquots of $150 \mu \mathrm{g}$ were precipitated and suspended in a final volume of $100 \mu \mathrm{l}$ of $0.41 \mathrm{M} \mathrm{PB}, 0.05 \%$ SDS, $1 \mathrm{mM}$ EDTA and $10^{4}$ cpm of the 610 nucleotide $A D H$ probe whose preparation was described above. Each sample was sealed in a glass capillary tube, boiled for $90 \mathrm{~s}$ then incubated at $60^{\circ} \mathrm{C}$ for $36 \mathrm{~h}$ to an equivalent Cot of $\geqslant 2500$. Samples were diluted to $0.12 \mathrm{M} \mathrm{PB}$, bound to $\mathrm{HAP}$ and thermally eluted in $4^{\circ} \mathrm{C}$ increments from $60^{\circ} \mathrm{C}$ to $98^{\circ} \mathrm{C}$ as described above.

Isolation of ADH-Containing $\lambda$ Clones. Genomic DNA of $D$. simulans and $D$. mauritiana was cloned in $\lambda$ Charon 4A (Blattner et al. 1977) using methods described by Maniatis et al. (1978) and kindly provided by Dr. M. Messelson. pSAC was labelled with ${ }^{32} \mathrm{p}$ by nick-translation and used to screen $\lambda$ libraries by modification of the method of Benton and Davis (1977) as described by Anderson et al. (1981). 60,000 recombinants of $D$. simulans were screened and four ADH-containing $\lambda$ clones were isolated. Five ADH $\lambda$ clones were isolated from 100,000 recombinants of $D$. mauritiana. Hybridization was done in $5 \times$ SSC, $1 \%$ Sarkosyl at $58^{\circ} \mathrm{C}$ and washes were done in $3 \times$ SSC, $0.5 \%$ Sarkosyl and $3 \times \mathrm{SSC}$ alone at $57-58^{\circ} \mathrm{C}$.

\section{Results}

\section{Evolutionary Divergence of Single-Copy DNA}

Measurement of thermal stability of heterologous DNA duplexes provides an estimate of average sequence difference in DNA of related species. The conditions of reassociation dictate which sequences are, or are not, too divergent to form stable duplex structures. Using low stringency conditions $\left(55^{\circ} \mathrm{C}, 0.41 \mathrm{M}\right.$ phosphate buffer) which maximize hybridization of divergent sequences, a series of reassociations were performed between single-copy, ${ }^{3} \mathrm{H}$ DNA from $D$. melanogaster and excess, unlabelled DNA of seven drosophilids. Figure 2 presents representative elution profiles obtained when the hybridization products were bound to hydroxyapatite, then eluted by incremental increase in temperature. Data from the measurements of Fig. 2, as well as others, are summarized in Table 1.

The $\mathrm{T}_{\mathrm{m}} 1 / 2$ of the $D$. melanogaster/D. melanogaster duplex was $84.1^{\circ} \mathrm{C}$ (Fig. 2, Table 1). This is close to the theoretical value of $84.6^{\circ} \mathrm{C}$, calculated using the equations of McConaughy et al. (1969) and Schildkraut and Lifson (1965), assuming 45\% G-C content of $D$. melanogaster DNA (Laird and McCarthy 1968). The closeness of the measured value to the theoretical $T_{m}$ $1 / 2$ demonstrates that the single-copy tracer was not extensively nicked or contaminated with repeat DNA, since length reduction or repeat contamination would have lowered the $T_{m} 1 / 2$ significantly. The hydroxy- 
Table 1. Divergence of single-copy DNAs measured by thermal elution from hydroxyapatite

\begin{tabular}{llllll} 
Species & $\begin{array}{l}\text { Number of } \\
\text { determinations }\end{array}$ & $\begin{array}{l}\text { Averagc } \\
\left.\mathrm{T}_{\mathrm{m}} 1 / 2 \mathrm{C}^{\circ} \mathrm{C}\right)^{\mathrm{a}}\end{array}$ & $\Delta \mathrm{T}_{\mathrm{m}} 1 / 2\left(^{\circ} \mathrm{C}\right)^{\mathrm{b}}$ & $\begin{array}{l}\text { Average } \\
\text { \% reaction }\end{array}$ & $\begin{array}{l}\text { Corrected } \\
\text { \% reaction }\end{array}$ \\
\hline D. melanogaster & 4 & 84.1 & - & 80.1 & 100 \\
D. simulans & 4 & 82.2 & 1.9 & 51.7 & 62.8 \\
D. mouritiana & 3 & 81.8 & 2.3 & 53.0 & 66.4 \\
D. pseudoobscura & 3 & 65.2 & 18.9 & 20.8 & 25.7 \\
D. hydei & 1 & 58.0 & 26.1 & 10.9 & 13.4 \\
D. willistoni & 3 & 57.6 & 26.5 & 13.4 & 16.5 \\
D. virilis & 3 & 57.9 & 262 & 15.1 & 18.6 \\
\hline
\end{tabular}

a The $T_{m} 1 / 2$ values in multiple determinations were averaged. The variance in multiple determinations was $\leqslant 1^{\circ} \mathrm{C}$ for the closely related species $(D$. melanogaster, $D$. simulans and $D$. mauritiana). In more distant species, variation was $\leqslant 2.5^{\circ} \mathrm{C}$

b The $\Delta T_{m} 1 / 2$ is the difference between the average $T_{m} 1 / 2$ observed for $D$. melanogaster/D. melanogaster duplexes and the average $T_{m} 1 / 2$ observed in heterologous measurements

c The percent reaction observed in multiple determinations was averaged; variation was $\leqslant 5 \%$ of the total reactivity

d The percent reaction was corrected for the reactivity of tracer which was $80.1 \%$

apatite method has some disadvantages relative to other melting techniques, notably the TEACl method discussed by (Britten et al. 1978). $\mathrm{T}_{\mathrm{m}} 1 / 2$ values measured by HAP elution are only reproducible to an accuracy of about $\pm 1^{\circ} \mathrm{C}$. However, in cases where both methods have been employed the results have been similar (e.g. Hall et al. 1980).

The results presented in Table 1 are generally consistent with the phylogeny shown in Fig. 1. The divergence between the sibling species $D$. melanogaster and $D$ simulans or $D$. mauritiana is much less $\left(\Delta \mathrm{T}_{\mathrm{m}} 1 / 2\right.$ of $1.9^{\circ} \mathrm{C}$ and $2.3^{\circ} \mathrm{C}$ respecitvely) than any of the other species compared. The divergence between $D$. melanogaster and $D$. pseudoobscura leads to a $\Delta \mathrm{T}_{\mathrm{m}} 1 / 2$ of $18.9^{\circ} \mathrm{C}$. According to the data listed in Table 1, these species, both in the sophophora radiation, are more closely related than is $D$. melanogaster with $D$. virilis or $D$. hydei. The data in Table 1 do not distinguish between the divergence of $D$. melanogaster and $D$. willistoni, $D$. hydei or $D$. virilis, all of whose genomes have little homology with $D$. melanogaster.

In addition to providing quantitation of sequence divergence, the data of Table 1 also show what fraction of single-copy DNA is capable of forming homologous and heterologous duplexes. This parameter is generally proportional to the phylogenetic relationships indicated both by Fig. 1 and by the melting data. However, measurement of the fraction of $D$. melanogaster singlecopy DNA capable of hybridization with total DNA of $D$. simulans or $D$. mauritiana yielded an unexpected result. Only about $65 \%$ of the $D$. melanogaster tracer hybridized with either of the other genomes. This result indicates that $\approx 35 \%$ of $D$. melanogaster single-copy sequences are totally absent in $D$. simulans and $D$. mauritiana or so modified that they fail to hybridize. This is true although 1) the $\Delta \mathrm{T}_{\mathrm{m}} 1 / 2$ of the duplexes which do form is very low, 2) $D$. melanogaster and $D$. simulans are extremely similar morphologically and can cross-mate and 3) the polytene chromosome banding patterns of these species are similar (Patterson and Stone 1952).

\section{Evolutionary Divergence of the ADH Gene Studied by Genomic Blotting}

The gene coding for ADH was studied in the same seven drosophilids. A plasmid containing the $D$. melanogaster $\mathrm{ADH}$ gene (pSAC, see Fig. 5) was labelled and used to probe Southern transfers of total genomic DNA; Fig. 3 shows the results. The intensity and position of the bands gives qualitative indication of how closely the $\mathrm{ADH}$ gene is related in each species to that of $D$. melanogaster. Analysis of several exposures of the blot shown in Fig. 3, as well as a number of other blots done under varying conditions lead to the synthesis of data shown in Table 2. No single set of conditions is appropriate to show clearly all the bands because the range of divergence in the seven species is too great. Each of the species appears to contain the ADH gene and the genes are similar enough to those of $D$. melanogaster to hybridize under the conditions used. The relationships of $D$. melanogaster to the other species as deduced from the ADH band intensities listed in Table 2 are consistent with the relationships indicated by comparison of total single-copy DNA shown in Table 1. Thus divergence of DNA coding for a single gene appears to reflect the vastly larger data base represented by total single-copy DNA. In the case of $D$. melanogaster, $D$. simulans and $D$. mauritiana not only are the bands of high intensity, the similarity in band size indicates conservation of restriction sites. Hybridization of another single-copy probe with genomic DNA of the same species yielded an identical ordering of species relatedness (L. Zwiebel unpublished observation). 


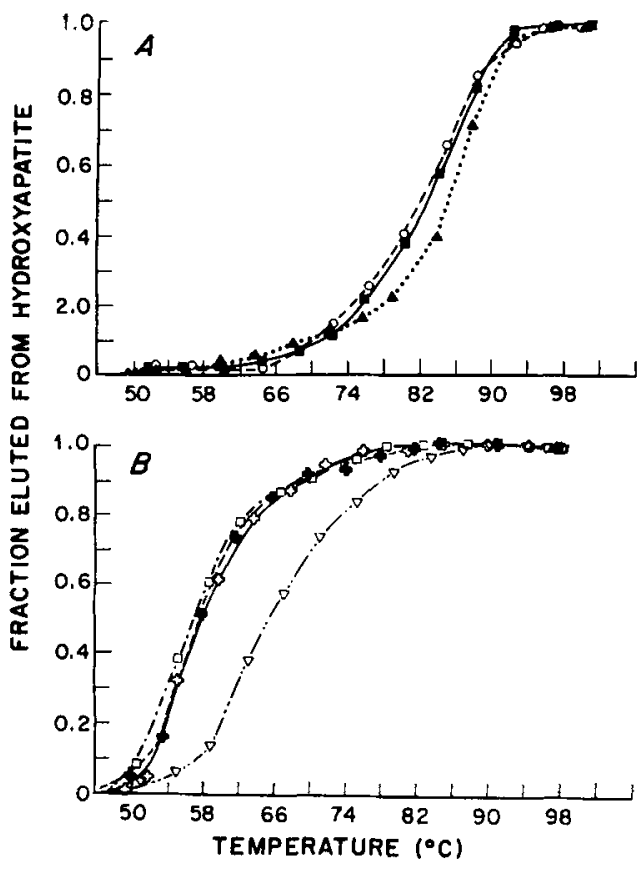

Fig. $2 \mathrm{~A}$ and B. Thermal elution from hydroxyapatite of duplexes formed between $\mathrm{H}^{3}$-labelled $D$. melanogaster single-copy DNA and excess total DNA of seven drosophilids. Reassociations were in $0.41 \mathrm{M} \mathrm{PB}, 0.05 \%$ SDS, $1 \mathrm{mM}$ EDTA at $55^{\circ} \mathrm{C}$ to equivalent $\operatorname{Cot}>2500 \mathrm{~mol} \mathrm{l^{-1 }}$ s. After hybridization, samples were diluted to $0.12 \mathrm{M} \mathrm{PB}$ and applied to a series of $0.4 \mathrm{~g}$ hydroxyapatite columns at $46^{\circ} \mathrm{C}$. Temperature was increased in approximately $4^{\circ} \mathrm{C}$ increments and the DNA fragments rendered single-stranded at each increment were eluted with $0.12 \mathrm{M}$ PB. Driver DNA's were: A (4) D. melanogaster, (o) D. matitiana, (匹) D. simulans; B ( D) D. pseudoobscura, (o) D. hydei, (+) D. willistoni, () D. virilis
Table 2. Order of band intensity in blots of Eco $R 1$ digested genomic DNA probed with pSAC

\begin{tabular}{lll}
\hline Species & $\begin{array}{l}\text { Band length } \\
(\mathrm{Kb})^{\mathrm{a}}\end{array}$ & $\begin{array}{l}\text { Ordered band } \\
\text { Intensity }^{\mathrm{b}}\end{array}$ \\
\hline D. melanogaster & $4.7^{\mathrm{c}}$ & 1 \\
D. simulans & 4.7 & $2^{\mathrm{d}}$ \\
D. mauritiana & 4.7 & $2^{\mathrm{d}}$ \\
$D$. pseudoobscura & $21,10.2,5.2$ & 4 \\
$D$. hydei & 6.8 & 5 \\
$D$. willistoni & $2.9,2.2$ & 6 \\
$D$. virilis & $\mathrm{e}$ & 7 \\
\hline
\end{tabular}

a Determined relative to the electrophoretic mobility of Hind III digested $\lambda$ DNA

b The intensity of the faint bands in Fig. 3 was photographically enhanced to show their positions more clearly. The order of band intensity was qualitatively determined from many blots carried out under a wide variety of hybridization conditions. No one set of hybridization conditions was appropriate for all of the species since the range of sequence divergence was great

c The faint band at $6.8 \mathrm{~Kb}$ seen in Fig. 3 was the product of incomplete digestion of $D$. melanogaster genomic DNA. The Eco RI site 5' to the ADH gene was incompletely digested leading to a larger fragment as shown in the restriction map of Fig. 5

d The intensity of the ADH band in D.mauritiana and D. simulans genomic DNA was not reproducibly different

e The signal was so weak that band position could not be reproducibly determined

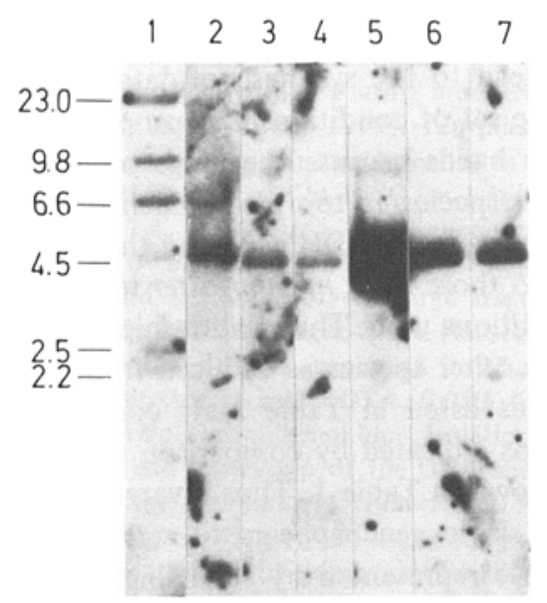

a

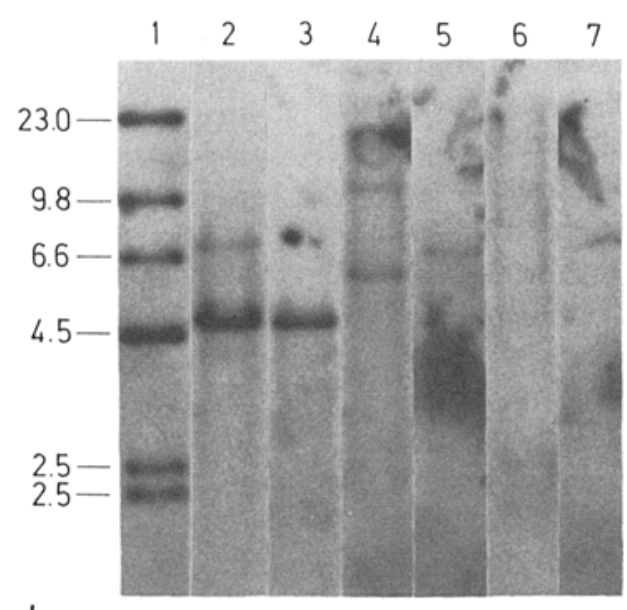

b

Fig. $3 \mathrm{~A}$ and B. Blot hybridization of a cloned ADH gene with genomic DNA of seven drosophilids. $2 \mu \mathrm{g}$ of each genomic DNA were digested with Eco RI and electrophoresed through a $0.7 \%$ agarose gel. The DNA was transferred to a nitrocellulose filter, hybridized with the probe ( ${ }^{32}$ P-labelled pSAC) DNA and autoradiographed, as described in the Methods section. The DNAs were A 1) Hind III digested $\lambda$ DNA, 2) $D$. melanogaster, 3) $D$. simulans, 4) $D$. mauritiana, 5) pSAC, 6) isolated ADH-containing $\lambda$ clone of $D$. simulans, 7) isolated ADH-containing $\lambda$ clone of $D$. mauritiana; B 1) Hind III digested $\lambda$ DNA, 2) D. melanogaster, 3) D. simulans, 4) $D$. pseudoobscura, 5) D. hydei, 6) D. willistoni, 7) D. virilis 
Some of the lanes of the blot shown in Fig. 3 contain more than one hybridizing band. In the D. melanogaster lane, the faint band at $6.8 \mathrm{~Kb}$ results from incomplete digestion of the Eco Rl site 5' to the ADH gene (see Fig. 5). Interestingly, the same site has been resistant to digestion in genomic clotes as well. It seems that the nucleotide sequence which makes up this particular Eco $\mathrm{R}_{1}$ site, or its immediate sequence enviromment, renders it a less suitable substrate for the enzyme than other Eco RI sites. However, more exhaustive digestion results in complete cleavage. The extra bands seen in digests of D. pseudoobscura and D. . hydei are probably not the result of partial digestion since hybridization with a different single-copy probe resulted in only one band (data not shown). Aside from-incomplete digestion, several explanatons are possible. These include muliple alleles in the population, hybridization of the $\mathrm{ADH}$ probe with a related sequence in the genome, or multiple copies of the ADH gene itself. There is genetic cuidence for the presence of more than one ADH gene in some species of drosophila (D. Sullivan personal communication)

\section{Evolutionary Divergence of the ADH Gene Studied Using Thermal Elution}

In order to quantitate interspecies divergence of the ADH gene, a 610 nucleotide fragment of $\mathrm{PSAC}$ was excess duplex genoric DNA of the seven species. The resultant luted were bound to hydroxyapatite and themally conted. As shown in Fig. 5 , the 610 nucleotide fragment nucleotins 125 nucleotides of 5 , flanking sequence, 420 the the ADH gene which is 65 nucleotides in length. Al flangh the 610 mucleotide probe contains some DNA the tem the ADH gene as well as one of the introns, hydroxyapatite at which DNA duplex elutes from sequence ele is dependent upon the most homologous sire elements. Thus this probe is suitable to mea re sequence divergence of the ADH structural gene.

Hg. 4 shows the themal elution profiles; the data are listed in Table 3. The order of species relatedness deduced from quantitation of divergence of the 610 nucleotide fragment is consistent with that generated from bloting (Table 2) and the singlecopy melts (Table 1). Comparisons of Tables 1 and 3 show that this fragment is more highly conserved during evolution than total single-copy DNA. Thus comparison of its divergence is better able to resolve patterns of relatedness in the more distant species. While D. willistoni. D. hydei and $D$. virilis appeared equally distant from $D$. melanogaster in Table 1, the order of their relatedness (with respect to the AOH gene) is resolved in Table 3 .

As a control, the separated strands of the 610 nucleotide fragment were mixed, reassociated and thermally

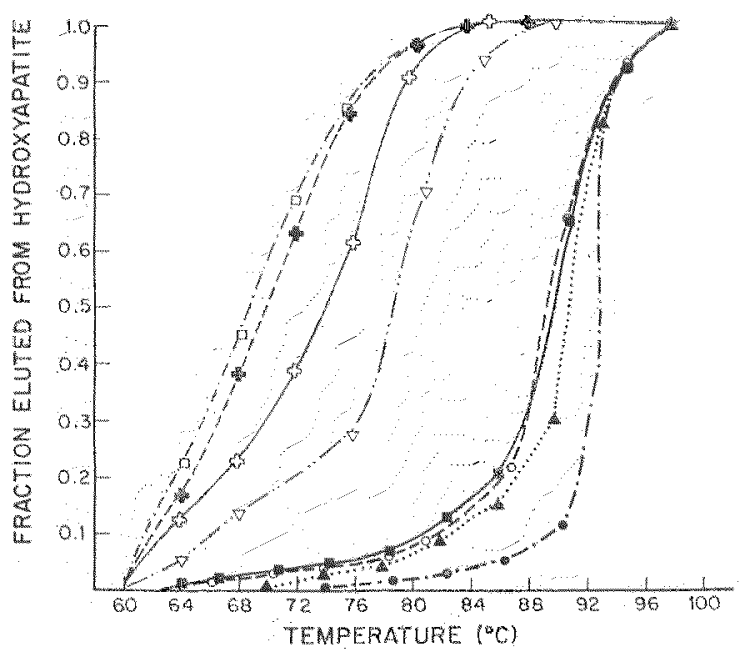

Fig. Themal elution from hy droxyaparte of dupleses formed berween 610 mucteotide fragment of PSAC and genomic DNA of seven drasophilds. The 610 nucteatide fragment (see Fig. 5 ) was endlabeled and strand-separated as descrbed in the Methods section. $150 \mathrm{\mu g}$ of driver and $5000 \mathrm{cpm}$ of tracer were incta bated in each reaction in $0.41 \mathrm{~PB}, 0.05 \%$ SDS, $1 \mathrm{mM}$ EDTA at $65^{\circ} \mathrm{C}$ to Cot $\geqslant 2000$. Thermal elution was as in Fig. 4 excet that the sample was appled to the column at $60^{\circ} \mathrm{C}$. Driver DNAs were ( tracer-tracer self reaction, (4) D. melanogizster, (o) D.

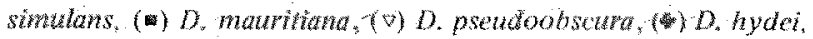
(4) D. willistoni, (a) D. wrilis

eluted from hydroxyapatite. The $\mathrm{r}_{\mathrm{m}} 1 / 2$ of the selfreassociated tracer was $92.8^{\circ} \mathrm{C}$. When individual strands of the tracer were reassociated with $D$. melanogaster DNA, the $T, 1 / 2$ of the resultant duplex was $90.8^{\circ} \mathrm{C}$ The cloned ADH gene was derived from Canton SD. me lanogaster while the driver DNA was Oregon $\mathrm{R}$ strain. Thus the $2^{\circ} \mathrm{C}$ reduction in $\mathrm{T}_{\mathrm{m}} 1 / 2$ of the driven duplex relative to the clone self-reassociation probably reflects divergence in the ADH gene between these two strains of $D$. melanogaster. The sibling species of D. melano gaster show a further reduction in $T_{\mathrm{n}} 1 / 2$ of only $0.8^{\circ} \mathrm{C}$. D. simulans and $D$. mauritiana are indistinguish. able. The $D$. pseudoobsidr ADH fragment is the next most related to $D$. melanogaster having a $\Delta \mathrm{T}_{\mathrm{m}} 1 / 2$ of $11.9^{\circ} \mathrm{C}$. This is consistent with the singlecopy melting data of Fig. 2 and the genomic blots shown in Fig. 3 . Again comparisons at the DNA level show that D. willistoni is more distantly related to D. melanogaster than $D$. pseudoobsctara or even $D$. hydet $D$. virilis is once more shown to be the most distantly related to $D$. meinogaster of the seven:

Comparison of the ADH Gene in D. melanogaster, $D$. simulans and D. mauritiana by Restriction Mapping

In order to initiate a more detailed analysis of the ADH gerie in closely and distantly related drosophilids, pSAC was used to screen genomic $\lambda$ clone libraries. The first result of these screens has been isolation of the ADH 
Table 3. Evolutionary divergence of a fragment of pSAC measured by thermal elution from hydroxyapatite

\begin{tabular}{|c|c|c|c|c|}
\hline Species & $\mathrm{T}_{\mathrm{m}} 1 / 2\left({ }^{\circ} \mathrm{C}\right)^{\mathrm{a}}$ & $\begin{array}{l}\text { Interspecies }{ }^{b} \\
\Delta T_{\mathrm{m}} 1 / 2\left({ }^{\circ} \mathrm{C}\right)^{b}\end{array}$ & $\begin{array}{l}\text { Polymorphic } \\
\Delta T_{m} 1 / 2\left({ }^{\circ} \mathrm{C}\right)\end{array}$ & $\begin{array}{l}\Delta T_{\mathrm{m}} \\
\mathrm{DNA}\left(\mathrm{C}^{\circ}\right)^{\mathrm{d}}\end{array}$ \\
\hline Tracer self-reassociation $^{\mathrm{e}}$ & $92.8^{\circ}$ & - & - & - \\
\hline D. melanogaster & $90.8^{\circ}$ & - & $2.0^{\circ}$ & - \\
\hline D. simulans & $90.0^{\circ}$ & $0.8^{\circ}$ & - & $1.9^{\circ}$ \\
\hline D. mauritiana & $90.0^{\circ}$ & $0.8^{\circ}$ & - & $2.3^{\circ}$ \\
\hline D. pseudoobscura & $79.0^{\circ}$ & $11.8^{\circ}$ & - & $18.9^{\circ}$ \\
\hline D. hydei & $74.0^{\circ}$ & $16.8^{\circ}$ & - & $26.1^{\circ}$ \\
\hline D. willistoni & $69.7^{\circ}$ & $21.1^{\circ}$ & - & $26.5^{\circ}$ \\
\hline D. virilis & $68.7^{\circ}$ & $22.1^{\circ}$ & - & $26.2^{\circ}$ \\
\hline
\end{tabular}

a The average $\Gamma_{\mathrm{m}} 1 / 2$ value in double determinations; variation was $\leqslant 1^{\circ} \mathrm{C}$

b The interspecies $\Delta T_{\mathrm{m}} 1 / 2$ is the difference between the average $T_{\mathrm{m}} 1 / 2$ observed for $D$. melanogaster/D. melanogaster duplex and the average $T_{m} 1 / 2$ observed in heterologous measurements

c The polymorphic $\Delta \mathrm{T}_{\mathrm{m}} 1 / 2$ is the difference between the average $T_{\mathrm{m}} 1 / 2$ of the self-reassociated tracer and the average $T_{m} 1 / 2$ observed when the tracer was reassociated with $D$. melanogaster DNA. The clone was derived from Canton $S$ while the driver was Oregon $R$ strain DNA

d From Table 1

e The two separated strands of the $D$. melanogaster 610 nucleotide fragment were reassociated with each other and the duplex thermally eluted from hydroxyapatite

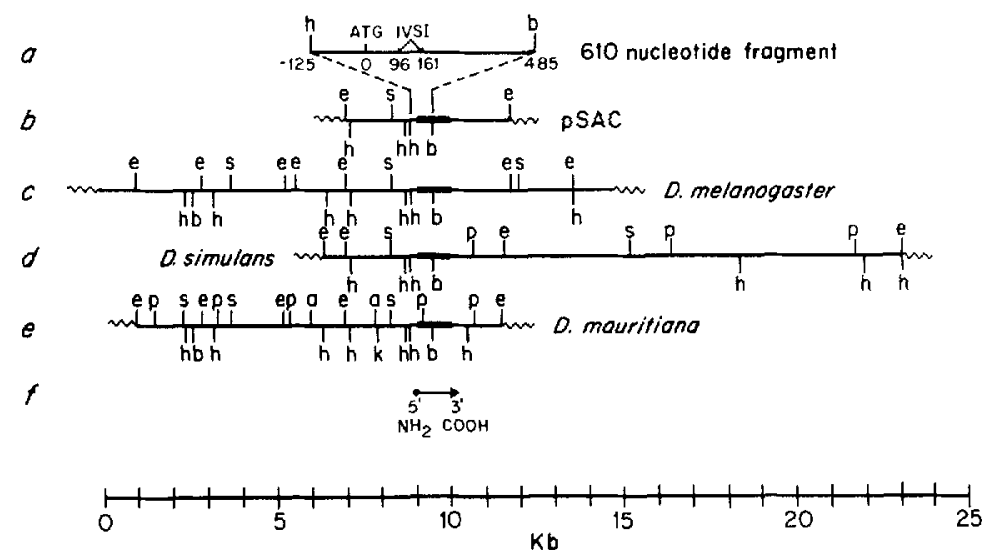

Fig. 5. Restriction maps of ADH-containing clones. $a$ The 610 nucleotide fragment used in Fig. 4 and Table 3, $b$ pSAC, an ADH-containing subclone from an isolated ADH-containing $\lambda$ clone from $D$. melanogaster (Goldberg 1980), $c$ an isolated $\mathrm{ADH}$-containing $\lambda$ clone from $D$. melanogaster (Goldberg 1980), $d$ an isolated ADH-containing $\lambda$ clone from $D$. simulans, $e$ an isolated ADH-containing $\lambda$ clone from $D$. mauritiana, $f$ The location and direction of transcription of the ADH gene. The symbols represent (-) drosophila DNA, ( $\sim$ ) vector DNA, (E) Eco Rl; (H) Hind III; (B) Bam HI: (S) Sal I; (P) Pst I; (A) Ava I; (K) Kpn I. Pst I, Kpn I, and Ava I sites were not available for $D$. melanogaster and Kpn I and Ava I sites were not determined for $D$. simulans

gene from $D$. simulans and $D$. mauritiana. In these species, as well as in $D$. melanogaster, the $\mathrm{ADH}$ gene resides in a $4.7 \mathrm{~Kb}$ Eco R1 fragment; this is shown in Fig. 3. Restriction maps of each clone were established by standard techniques and are shown in Fig. 5. The restriction map of the $D$. melanogaster ADH containing $\lambda$ clone has been published previously (Goldberg 1980). The direction of transcription of the gene has been established by sequencing (Benyajati et al. 1981). The $D$. simulans and $D$. mauritiana maps show a number of sites in common with each other and with $D$. melanogaster. Comparison of these sites allows orientation of the gene whose 5 ' end resides very close to a Hind III site common to all three species. In addition to the common Hind III site, $D$. melanogaster, $D$. simulans and $D$. mauritiana also share two Eco R1 sites, a Sal I site and two additional Hind III sites flanking the ADH gene. There is also one conserved Bam site within the gene. Pst I sites have not been mapped in $D$. melanogaster but there is one site shared between $D$. simulans and $D$. mauritiana as well as one which is not shared. There is a high degree of restriction site sharing within and directly flanking the ADH gene in the three sibling species. Although the number of sites compared does not allow quantitation of sequence divergence, this provides independent evidence of the similarity of these genomes, and suggests that this gene and its immediate sequence environment may represent a region of conserved DNA sequence.

\section{Discussion}

Use of Interspecies Comparison at the DNA Level to Assess Species Relatedness

Four different techniques have been used to assess the relatedness of seven drosophilids at the DNA level. These were thermal elution of interspecies single-copy DNA hybrids, genomic blotting using the cloned ADH gene 
as a probe, thermal elution of interspecies hybrids of $\mathrm{ADH}$, and in a limited set of measurements, restriction mapping of isolated ADH-containing genomic clones. Phylogenetic conclusions based on divergence of a single gene are subject to uncertainty. However, based on the measurements reported here, a consistent ordering of the relatedness of these species to $D$. melanogaster was obtained and can be compared to that predicted by the phylogeny in Fig. 1. An unexpected finding was that $D$. willistoni, thought to have diverged from the line leading to $D$. melanogaster at about the same time as $D$. pseudoobscura (Throckmorton 1975), was found by several lines of evidence to be much more distantly related to $D$. melanogaster. Beverley and Wilson (1982) have recently come to a similar conclusion based on immunological evidence. With respect to ADH, Table 3 shows $D$. willistoni to be more distant even than $D$. hydei and this is supported by the blot of Fig. 3. There are two possible interpretations of this result. One is that the phylogeny is simply incorrect regarding placement of $D$. willistoni. A second is that after divergence from the line leading to $D$. melanogaster, the $D$. willistoni line diverged at a much more rapid rate than the line leading to $D$. pseudoobscura. While less striking than the divergence of $D$. willistoni, the phylogeny shown in Fig. 1 did not predict that $D$. hydei would appear to be more closely related to $D$. melanogaster than would $D$.
virilis.

\section{Rate of Single-Copy DNA Divergence}

Because of the lack of fossil evidence, it is extremely difficult to estimate divergence times for drosophilids. The best available estimate of divergence time between $D$. melanogaster and $D$. virilis is about forty million years (Throckmorton, personal communication). Referring to data of Table 1 , and assuming $1^{\circ} \mathrm{C}$ change in $\mathrm{T}_{\mathrm{m}}$ $1 / 2$ corresponds to $1 \%$ sequence mismatch (Britten et al.
1974) we can calculate a change of $26.2 / 40=0.66 \%$ of bases per million years for the $18.6 \%$ of single-copy DNA which is still similar enough to form interspecific duplex. Since $81.4 \%$ of the $D$. virilis genome is too divergent to hybridize with $D$. melanogaster at all, the estimate of $0.66 \%$ per million years is clearly a lower limit. Calculation of this average rate does not necessarily imply a constant rate over time. The minimum rate of divergence of $0.66 \%$ per million years for single-copy DNA in drosophila is similar to the rate calculated for sea urchin DNA of 0.5\% per million years (Hall et al. 1980). In Hawaiian drosophila, a rate of $0.4 \%$ per million years has been reported (Hunt et al. 1981). A slower rate, 0.1\% per million years, has been reported for primate DNA's (Britten and Davidson 1976).

\section{The Nature of Single-Copy DNA Divergence}

There are some clear differences between the nature of single-copy DNA divergence observed here and that reported in other interspecies comparisons. For example, Angerer et al. (1976) compared two distantly related species of sea urchin i.e. $S$. purpuratus and $L$. pictus. Only about $12 \%$ of the single-copy DNA was crosshybridizable. However, the $\mathrm{T}_{\mathrm{m}} 1 / 2$ of that $12 \%$ was relatively high, demonstrating the existence of a conserved class of single-copy DNA. In contrast, the distantly related drosophilids compared here do not contain an analogous conserved component in their genomes. An interesting observation of this study is that the genome of D. melanogaster appears to contain a large, rapidly evolving, single-copy component. This follows from the finding that about $35 \%$ of $D$. melanogaster single-copy fails to hybridize with $D$. simulans or D. mauritiana total DNA (Table 1). A similar observation has recently been reported in comparisons of closely related species of Hawaiian drosophila (Hunt et al. 1981). That these observations in drosophila are unusual can be seen from

\begin{tabular}{|c|c|c|c|}
\hline Species compared & $\begin{array}{l}\text { Single-copy } \\
\Delta \mathrm{T}_{\mathrm{m}} 1 / 2\left({ }^{\circ} \mathrm{C}\right)\end{array}$ & $\%$ Reaction & Source \\
\hline $\begin{array}{l}\text { S. purpuratus/S. franciscanus } \\
\text { Mouse/Rat }\end{array}$ & $14^{\circ}$ & $\begin{array}{l}90 \% \\
80-85 \%\end{array}$ & $\begin{array}{l}\text { Hall et al. (1980) } \\
\text { Kohne et al. (1972) }\end{array}$ \\
\hline $\begin{array}{l}\text { Man/Capuchin } \\
\text { Cow/Pig }\end{array}$ & $10.5^{\circ}$ & $90-95 \%$ & $\begin{array}{l}\text { Rosbash et al. (1975) } \\
\text { Kohne et al. (1972) }\end{array}$ \\
\hline Individual S. purpuratus/ & $14^{\circ}$ & $80 \%$ & Kohne et al. (1972) \\
\hline $\begin{array}{c}\text { Second individual } S \text {. purpuratus } \\
D . \text { heteroneura }\end{array}$ & $4^{\circ}$ & $95 \%$ & Britten et al. (1978) \\
\hline $\begin{array}{l}\text { Dicticornis/ or } \\
\text { D. silvestris } \\
\text { D. simulans }\end{array}$ & $2.1^{\circ}$ & $62 \%$ & Hunt et al. (1981) \\
\hline $\begin{array}{r}\text { Delanogaster/ or } \\
\text { D. mauritiana }\end{array}$ & $2.1^{\circ}$ & $65 \%$ & $\begin{array}{l}\text { Average of data from } \\
\text { Table } 1 \text { of this paper }\end{array}$ \\
\hline
\end{tabular}


data listed in Table 4. The first four comparisons show instances where evolutionary sequence divergence has lowered the melting point of interspecific duplexes by a large amount i.e. $10-18^{\circ} \mathrm{C}$. However, most of the singlecopy DNA of these genomes remains cross-hybridizable (80-95\%). In fact, for a large number of published comparisons (of which those in Table 4 are only a fraction) it is generally true that the extent of inter-species hybridization remains relatively high even when sequence divergence reaches a level of $10-15 \%$. In very distantly related species, of course, cross-hybridization is low. In very closely related organisms, such as the comparison of two individual $S$. purpuratus cited in Table 4 , crosshybridization is essentially complete and $\Delta T_{m} 1 / 2$ is low.

The last two citations of Table 4 show comparisons of drosophilids known by several criteria to be closely related. As expected, the $\Delta \mathrm{T}_{m} 1 / 2$ is small. Surprisingly however, a significant fraction of the single-copy DNA fails to cross-hybridize at all. It appears that drosophilids are undergoing two completely different evolutionary processes. One is the normal accumulation of mutations common to DNA of all species. A second is a rapid process which results in lack of hybridization between a large fraction of the genome of closely related species. This second process is not seen in the other species listed in Table 4 and may be unique to drosophila. The recent discovery of mobile elements in drosophila genomes (e.g. Strobel et al. 1979) suggests that processes of insertion and deletion of such elements might explain the results obtained here. Such mobile elements have not been previously reported in single-copy DNA.

$D$. melanogaster and $D$. simulans have similar polytene chromosome banding patterns and interspecific hybrids exhibit almost normal chromosomal pairing (Patterson and Stone 1952). Thus it is unlikely that rapidly evolving DNA is all located in one or a few regions of the genome. If it were, these regions would be evident as areas where homologous chromosomes could not pair in interspecific hybrids. Therefore it seems likely that rapidly evolving DNA is interspersed throughout the genome with DNA undergoing the more usual processes of evolution. On the other hand, rapidly evolving DNA probably is not interspersed with a very short periodicity. The tracer used in the measurements listed in Table 1 had a length of about 500 nucleotides. If interspersion periodicity were much shorter than 500 nucleotides, most tracer molecules would contain both rapidly evolving and "normal" DNA. These molecules would form duplexes in the interspecific hybridization experiments and a larger cross-hybridization would have been observed. Thus the rapidly evolving DNA is neither localized in one or a few positions, nor interspersed at short periodicity. It must, therefore, be interspersed in many genomic locations but with an average spacing considerably greater than 500 nucleotides. Further characterization of rapidly evolving DNA must await cloning and detailed study of individual sequences.

Acknowledgements. We thank M. Hudspeth for help in preparation of the 610 nucleotide fragment of the D. melanogaster ADH gene. The technical assistance of $R$. Melander, J. Pshea, W. McCay and T. Thompson as well as helpful discussions with $W$. Brown, S. Berger and L. Throckmorton are gratefully acknowledged. This work was supported by NIH Grant GM-28851 to G.P.M. and NIH training grants GM-07315 (V.H.C.) and GM07544 (L.J.Z.).

\section{References}

Anderson DM, Sheller RH, Posakony JW, McAllister LB, Trabert SG, Beall C, Britten RJ, Davidson EH (1981) Repetitive sequences in the sea urchin genome. I. Distribution of members of specific repetitive families. J Mol Biol 145:5-28

Angerer RC, Davidson EH, Britten RJ (1976) Single copy DNA and structural gene sequence relationships among four sea urchin species. Chromosoma 56:213-226

Benton WD, Davis RW (1977) Screening $\lambda$ recombinant clones by hybridization to single plaques in situ. Science 196: $180-182$

Benyajati C, Wang N, Reddy A, Weinberg E, Sofer W (1980) Alcohol dehydrogenase in Drosophila: Isolation and characterization of messenger RNA and cDNA clone. Nucleic Acids Res 8:5649-5665

Benyajati C, Place AR, Powers DA, Sofer W (1981) Alcohol dehydrogenase gene of Drosophila melanogaster: Relationship of intervening sequences to functional domains in the protein. Proc Natl Acad Sci USA 78:2717-2721

Beverley SM, Wilson AC (1982) Molecular evolution in Drosophila and higher diptera I: Micro-complement fixation studies of a larval hemolymph protein. J Mol Evol 18: $251-264$

Blattner FR, Williams BG, Blechl AE, Denniston-Thompson K, Faber HE, Furlong LA, Grunwald DJ, Keifer DO, Moore DD, Schumm JW, Sheldon EL, Smithies O (1977) Charon phages: Safer derivatiues of bacteriophage lambda for DNA cloning. Science 196:161-169

Britten RJ, Kolne DE (1967) Nucleotide sequence repetition in DNA. Carnegie Inst Wash Yearbook 65:98-117

Britten RJ, Graham DE, Neufeld BR (1974) Analysis of repeating DNA sequences by reassociation. In: Grossman L, Moldave $K$ (eds) Methods in Enzymology 29 E, Academic Press, New York, p 363

Britten RJ, Davidson EH (1976) DNA sequence arangement and preliminary evidence on its evolution. Fed Proc 35:21512157

Britten RJ, Cetta A, Davidson EH (1978) The single-copy DNA sequence polymorphism of the sea urchin Strongylocentrotus purpuratus. Cell 15:1175-1186

Clewell DB, Helinski DR (1972) Effect of growth conditions on the formation of the relaxation complex of supercolied $\mathrm{Col}$ E1 desoxyribonucleic acid and protein in Escherichia coli. J Bacteriol 110:1135

Drouin J, Symons RJ (1979) In: Cummings D, Borst P, David I, Weisman S, Fox G (eds) Extra Chromosomal DNA, ICNUCLA Symposia vol 15 Academic Press, New York, pp 471484 
Efstratiadis A, Posakony JW, Maniatis T, Lawn RM, O'Connell C, Spritz RA, DeRiel JK, Forget BG, Weissman SM, Slighton IL, Blechel AF, Smithies O, Baralle FE, Shoulders CC, Proudfoot NJ (1980) The structure and evolution of the human B-globin gene family. Cell 21:653-668

Galau GA, Britten RJ, Davidson EH (1974) A measurement of the sequence complexity of polysomal messenger $R N A$ in sea urchin embryos. Cell 2:9-21

Goldberg DA (1980) Isolation and partial characterization of the Drosophila alcohol dehydrogenase gene. Proc Natl Acad Sci USA 77:5794-5798

Hall TJ, Grula JW, Davidson EH, Britten RJ (1980) Evolution of the sea urchin non-repetitive DNA. J Mol Evol 16:95-110

Hunt JA, Hall TJ, Britten RJ (1981) Evolutionary distances in Hawailan Drosophila measured by DNA reassociation. J Mol Evol $361-367$

Hutton JR, Wetmur JG (1973) Effect of chemical modification on the rate of resaturation of deoxyribonucleic acid: Deaminated and glyoxalated deoxyribonucleic acid. Biochemistry 12:558-563

Klenow $\mathrm{H}$, Overgaard-Hansen OK (1976) The N-terminal amino acid sequences of DNA polymerase I from Escherichia coli and of the large and small fragments obtained by a limited proteolysis. Eur J Biochem 45:623-627

Kohne DE, Chiscon JA, Hoyer BH (1971) Carnegie Inst Wash Yearbook 69:488-502

Laird CD, McCarthy BJ (1968) Magnitude of interspecific nucleotide sequence variablity in Drosophila. Genetics 60 : $303-322$

Maniatis T, Hardison RC, Lacy E, Laver J, O'Connell C, Quon D, Sim GK, Efstratiadis A (1978) The isolation of structural genes from libraries of eucaryotic DNA. Cell 15:687-701

Maniatis $T$, Fritsch EF, Sambrock I (1981) In: Molecular Cloning Cold Spring Harbor publishers.

Maxam A, Gilbert W (1977) A new method for sequencing DNA. Proc Natl Acad Sci USA 77:5791 -5798

McConaughy BL, Laird CD, McCarthy BJ (1969) Nucleic acid reassociation in formamide. Biochemistry 8:3289-3295
Moore GP, Scheller RH, Davidson EH, Britten RJ (1978) Evolutionary change in the repetition frequency of sea uchin DNA sequences. Cell 15:649-660

Nolt H (1967) Characterization of macromolecules by constant velocity sedimentation. Nature 215:360-363

Patterson JT, Stone WS (1952) In: Evolution in the Genus Drosophila. McMillan, New York

Perler F, Efstratiadis A, Lomedico P, Gilbert W, Kolodner R, Dodgson J (1980) The evolution of genes: the chicken preproinsulin gene. Cell 20:555-556

Rigby PW, Dieckman M, Rhodes C, Berg P (1977) Labeling deoxyribonucleic acid to high specific activity in vitro by nick translation with DNA polymerase I. J Mol Biol 113:237-251

Rosbash M, Campo MS, Gummerson KS (1975) Conservation of cytoplasmic poly(A)-containing RNA in mouse and rat, Natuse 258:682-686

Schidkraut C, Lifson N (1965) Dependence of the melting temperature of DNA on salt concentration. Biopolymeres 3: 195-208

Southern EM (1975) Detection of specific sequences among DNA fragments seperated by gel electrophoresis. J Mol Biol 98:503-517

Sperlick D (1962) Dros Info Ser 36:118

Strobel E, Dunsmuir P, Rubin G (1979) Polymorphisms in the chromosomal locations of elements of the 412, Copia and 297 dispersed repeated gene family in Drosophila. Cell 17: 429-439

Studier FW (1965) Sedimentation studies of the size and shape of DNA. J Mol Biol 11:373-390

Thatcher D (1980) The complete amino acid sequence of 3 alcohol dehydrogenase alloenzymes. Biochem J 187:875-886

Throckmorton LH (1975) In: King RC (ed) Hanbook of Gene tics Volume ? Plenum Press, New York, p $421-469$

Wilson AC, Carlson SS, White TJ (1977) Biochemical evolution. Annu Rev Biochem 46:573-639

Received Aprii 19, 1982/Revised August 6, 1982 